\title{
CZY ISTNIAŁ MECENAT WYDAWNICZY WOBEC KSIAZŻKI NAUKOWEJ W XIX WIEKU?
}

Od wielu już lat pojawiają się postulaty zbadania szczególnej roli mecenatu wobec polskiej kultury w okresie zaborów, również w dziedzinie publikacji naukowych. Historycy uważają tę kartę dziejów kultury za wyjątkowo interesującą, gdyż wtedy to staraniem osób prywatnych, działających indywidualnie, bądź skupionych w instytucjach i stowarzyszeniach, udało się zainicjować wiele przedsięwzięć, które zadecydowały o utrzymaniu i rozwoju polskiej tożsamości narodowej. Wystarczy przypomnieć o powstałych wówczas bibliotekach, bibliografii Estreicherów, czy encyklopedii Orgelbranda.

Ta karta historii polskiej kultury nie została jednak w literaturze historycznej należycie opracowana. Sczególnie wyraźnie ilustruje to brak kompetentnych opracowań historii ksiażki. Nie doczekały się odrębnego potraktowania dzieje bibliotek wielkoziemiańskich powstałych w XIX wieku staraniem prywatnym. „Postulat takich badań jest bezsporny" - stwierdziła Zofia Gaca-Dąbrowska w 1982 r. ${ }^{1}$, a inni autorzy zarysowali propozycję modelu takich badań, ilustrując ja przykładami udanych rozwiązań poszczególnych problemów². Pojawiły się mniej czy bardziej udane przyczynki - oczekiwana monografia nie ujrzała jednak światła dziennego.

innym ważnym problemem wspierania książki w XIX wieku był mecenat wydawniczy. Choć jego osiąnięcia są powszechnie znane i akceptowane - naukowe ich opracowanie wydaje się również sprawą przyszłości ${ }^{3}$. Co najwyżej powstają, choć z wolna, przyczynki wnoszące nowe elementy. Pojawiają się np. opracowania działalności wydawniczej poszczególnych mecenasów. Andrzej Biernacki w wartościowym studium opisał perypetie i sukcesy Aleksandra Przeździeckiego jako wydawcy pełnego wydania dzieł Jana Długosza ${ }^{4}$. Aktywność na polu mecenatu wydawniczego obu Działyńskich, Tytusa i Jana, opisywano już wielokrotnie. Autor niniejszego artykułu dokonał tego w kilku pracach, a trudy wydawnicze Jana Działyńskiego podsumował w monografii, poświęconej tej postaci ${ }^{5}$.

Inną pracą, w której autor zajął się mecenatem wydawniczym, była imponująca zasiegiem kwerendy źródłowej monografia Juliana Dybca o mecenacie galicyjskim ${ }^{6}$. W rozdziale poświęconym mecenatowi wydawniczemu (s. 94-146) scharakteryzowat kolejno: ruch wydawniczy w Galicji, mecenat indywidualny, zbiorowe popieranie wydawnictw, a w tym: wydawnictwa ludowe i popularne, podręczniki szkolne, wydawnictwa naukowe i czasopisma specjalistyczne. Zdaniem autora autonomia Galicji, rozwój nauki, wzrost liczby ludzi piszących z jednej strony, a głód polskiej książki z drugiej, wywołały potrzebę uaktywnienia się prywatnego i zbiorowego mecenatu wydawniczego. Wyzwaniu temu na ogół Galicja sprostała. J. 
Dybiec doszedł do takich właśnie wniosków, analizując zapotrzebowanie czytelnicze, repertuar wydawniczy, wielkość produkcji, sumy wyłożone przez mecenasów na finansowanie poszczególnych typów wydawnictw, jak i indywidualnych książek.

Omówione wyżej nieliczne prace, przynoszące opracowania fragmentów rozległego przecież mecenatu wydawniczego w XIX wieku, przyjmowały na ogół milcząco, iż panuje zgoda co do znaczenia samego terminu „mecenat wydawniczy”, czy „kulturalny”. J. Dybiec nie podał nawet krótkiej definicji zjawiska, któremu poświęcił całą książkę, zauważył tylko, że $w$ wieku XIX mecenat na ziemiach polskich pod wpływem zagrożenia politycznego i kulturalnego przybrał charakter narodowy. Poszerzyło się środowisko mecenasów, w którego krag weszli przedstawiciele mieszczaństwa, burżuazji, inteligencji, a także chłopów. Mecenat wydawniczy podzieli J. Dybiec na indywidualny (prywatny) i zbiorowy. Pienwszy polegał na „doraźnym, osobistym finansowaniu różnych wydawnictw”, czasem „przybierał postać funduszów wydawniczych"8. Doraźnie finansowano w Galicji książki związane z przeszłością narodową, fragmentarycznie - inne prace, $\mathrm{np}$. z historii powszechnej czy nauk ścisłych. Więcej pożytku kulturze narodowej przyniosły fundusze wydawnicze, a więc dary i zapisy dla poszczególnych instytucji, przeważnie dla Akademii Umiejętności, wykorzystywane zgodnie z planami naukowymi i wolą testatorów.

Mecenat zbiorowy organizowały towarzystwa i instytucje, choć niektóre mogły być popierane przez osoby indywidualne. J. Dybiec ma pewne kłopoty $z$ owym mecenatem zbiorowym. Wydaje się, że chce w nim „zmieścić” zbyt wiele form finansowania wydawnictw. Jako akcję mecenasowską traktuje więc subskrypcję, gdyż - to prawda - w akcji takiej brało udział wiele osób. To fakt, że dzięki rozpisywanym subskrypcjom ukazała się $w$ XIX wieku duża ilość książek naukowych, niemniej subskrybenci nie wpłacali przecież pieniędzy bezinteresownie otrzymywali książki po ich wydaniu. Za mecenat uznaje też pomoc władz miejskich w akcji wydawniczej, co już zupełnie chyba nie powinno wchodzić w grę, tym bardziej, gdy miasto opierało swój budżet na dotacjach centralnych.

Czymże jest więc mecenat wydawniczy i jakie ograniczenia trzeba mu postawić? $W$ jednym $z$ artykułów, w którym chciałem pokazać potrzebę włączenia do badań nad dziewiętnastowieczną książką polską zagadnienia działalności prywatnego mecenatu wydawniczego w dziedzinie piśmiennictwa naukowego, kilka słów

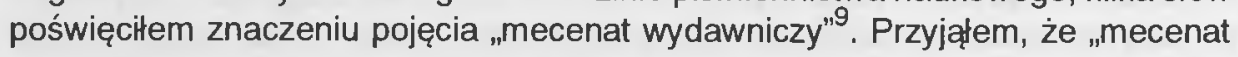
to bezinteresowna i wszechstronna opieka nad twórczością artystyczną, bądź też naukową". Podkreślić należy tu zasadniczy moment „bezinteresowności" mecenasa, choć takie rozumienie mecenatu zrodziło się dopiero w wieku XIX, w którym opieka nad uczonym i artystą nabrała charakteru bezinteresownego. W wiekach ubiegłych - począwszy od starożytności - mecenat oznaczal związek dwóch stron, świadczących sobie usługi: mecenasa i artysty. Przyjąwszy takie stanowisko, mecenatem nazwałem bez wahania zbiorowe popieranie wydawnictw, np. działalność Kasy im. Mianowskiego. Pewien kłopot jednak sprawiają nakładcy indywidualni i takie wątpliwości zgłosiłem już wtedy. Bardzo rzadko było bowiem tak, żeby nakładca nie był „uwikłany" w jakiś sposób w finansowane przez siebie dzieło, na przykład jako autor, wydawca, czy tłumacz, a jego bezinteresowności nie można 
było poddać $w$ wątpliwość. Przykładem może być olbrzymia produkcja wydawnicza Edwarda Raczyńskiego, który publikowanym przez siebie tekstom towarzyszył od początku do końca, a więc od odszukania i wyboru materiałów źródłowych, poprzez ich opracowanie (adaptację) do publikacji ${ }^{10}$. Podobne wątpliwości budzą publikacje, o których wspomniał J. Dybiec, a mianowicie opracowania historii poszczególnych rodzin czy tekstów źródłowych z nimi związanych ${ }^{11}$. Czy ci wydawcy, będący często autorami przeróżnych kronik rodzinnych byli mecenasami nauki, czy zaspokajali tylko potrzeby własnej ambicji rodowej? Nawet w sytuacji bardziej przejrzystej, gdy nakładca finansuje cudze dzieła według widocznego programu naukowego, wynikającego z bieżącej sytuacji nauki, społecznie użytecznego, również wtedy czai się cień wątpliwości - czy aby akcja ta jest całkowicie bezinteresowna? Jan Działyński, który wydał swoim nakładem 55 woluminów dzieł naukowych, opłacając zarówno honoraria autorów, jak i cały proces wydawniczy, powinien być przykładem mecenasa bezinteresownego. Niemniej, nawet i on starannie dbał, by wydawnictwa te uznawano za osiaggnięcia Biblioteki Kórnickiej, której był zarazem właścicielem i opiekunem, a której dobra sława była przedmiotem jego starań i ambicji.

Trzeba więc chyba pogodzić się z faktem, iż nie spotkamy się z przykładami mecenatu indywidualnego idealnie czystego, a więc pozbawionego elementów własnej ambicji i korzyści. Nie powinno to, oczywiście, peszyć badaczy tego problemu. Mimo tego, że poszczególni wydawcy nie mieszczą się z reguły bez reszty w formule „bezinteresownej opieki nad twórczością naukową", nie umniejsza to ich zasług dla kultury polskiej, a złożoność motywów ich działania tym bardziej zachęca do ich zbadania. Ponadto - ta indywidualna motywacja, interesująca dla autorów poszczególnych biografii wybitnych mecenasów XIX wieku - jest mniej istotna w odniesieniu do ówczesnej sytuacji nauki. Można tu przytoczyć i inny argument za uznaniem tej działalności za „bezinteresowna”. O ile kolekcjoner sztuki, zamawiając obraz czy rzeźbę staje się ich posiadaczem, co utrudnia mu zrozumienie istotnej wartości dzieła sztuki, to wynalazki naukowe, twórczość literacka a i edycje dzieł naukowych powstałe na tej drodze, stają się prędzej czy później własnością publiczną, rozpoczynają swój autonomiczny społeczny żywot ${ }^{12}$. Ta przynależność własnościowa zbliża najwyraźniej działalność wydawców dzieł naukowych do mecenatu "czystego" - nieobciażonego podejizeniem o chęć podbudowania własnego prestiżu. Czy jednak pobudek takich nie można wykluczyć? Powtórzmy - oczywiście nie - efektowna edycja zaspokajała również własne ambicje naukowe, a może i miłość własną nakładcy. Niezależnie jednak od motywów działania nakładców, o których zresztą nie zawsze wszystko wiadomo, wynikiem ich działań było udostępnienie spoleczeństwu tekstów naukowych, a więc spełnienie tego podstawowego kryterium mecenatu, bardzo trafnie wyodrębnionego przez J. Białostockiego.

Powyższa opinia wybitnego historyka sztuki jest tylko jednym z głosów przedstawicieli tej dyscypliny nauki $w$ dyskusji, która niespodziewanie żywo rozwinęła się $w$ latach $80-$ tych $^{13}$. Historycy sztuki dużą wage przywiazują do określenia istoty mecenatu w dziedzinie szeroko rozumianej działalności w obszarze kultury. To zrozumiałe - pałace, rzeźby, obrazy czy nawet ogrody, powstawały w przeszłości w większości z woli królów, książąt, patrycjatu świeckiego czy kościelnego - stąd 
znaczenie pytań o motywy działania fundatorów, ich upodobania artystyczne, czy możliwości finansowe. Dyskusja ta powinna zainteresować również historyków polskiej ksiażki, ponieważ i jedni i drudzy mówią i piszą o zjawisku wspólnym mecenacie, rozumiejąc go jednak w sposób nieco odmienny. Gwoli prawdy powiedzieć trzeba, że teoretyczne aspekty mecenatu wydawniczego nie były nigdy przedmiotem odrębnej refleksji historyków książki, toteż trudno tu mówić o odmiennych stanowiskach. Głosy i opinie historyków sztuki rozszerzają pole zainteresowań, wychodząc bez wątpienia poza zainteresowania bibliologów. Niemniej pewne pytania wydają się wspólne, a ich rozstrzygnięcie, w każdym razie zasygnalizowanie, pozwoli precyzyjnie operować terminem „mecenat wydawniczy”, a co za tym idzie - zawęzić lub rozszerzyć pole badawcze. W dyskusjach nad określeniem pojęcia „mecenat” podnosi się zasadniczą dla jego zrozumienia sprawę motywów, a więc obok „idealnych" (miłość do sztuki), również społeczno-politycznych, chęć zysku z lokaty kapitału ${ }^{14}$. Generalnie natomiast stwierdza się, że problematyka mecenatu jest daleka od jednoznacznego rozwiązania, a ostateczne rozstrzygnięcia-dalekie ${ }^{15}$.

Dodatkowy kłopot historyków sztuki jest nieco inny, niż historyków książki. Podczas gdy ci ostatni zastanawiają się na przykład, czy autor (wydawca) dzieła będący jednocześnie jego nakładcą, może być traktowany jako mecenas, historyk sztuki pyta o to samo w sposób odmienny, to znaczy czy nakłady poniesione na dzieła sztuki były częścią „polityki artystycznej” panujących czy możnowładców, dążących do zwiększenia swej siły i prestiżu, czy też działaniem autentycznych opiekunów artystów i architektów. J.A. Chrościcki proponuje, by terminu „mecenat" używać oszczędniej. Panujący czy magnaci budowali przecież własny prestiż i polityczne znaczenie poprzez stawianie rezydencji czy ozdabianie ich dzielami sztuki. Trzeba przyjąć ostrzeżenia J.A. Chrościckiego przed nadmiernym szafowaniem terminem „mecenat" również w odniesieniu do wydawnictw. XVII czy XVIIIwieczny panegiryk wydany sumptem wysławianego w nim możnowładcy jest przecież elementem kreowanego przez niego image'u, a nie osiąnięciem mecenasowskim. To oczywiste. Problem komplikuje się w XIX wieku, o czym wspomnieliśmy wyżej. Nie ulega wątpliwości, że w tym okresie właśnie staraniem osób prywatnych, również organizacji społecznych ujrzała światło dzienne znaczna liczba woluminów książki naukowej. Czy więc wydawcy ci, szczególnie indywidualni byli mecenasami? Wydaje się, że w o wiele większym stopniu, niż zamawiający u artystów dzieła sztuki czy wystawiający pałace możnowładcy, którzy są wyłącznymi wlaścicielami tych wytworów i używają ich w sposób przez siebie uznany za najwłaściwszy. J.A. Chrościcki uważa też, że nietrafny jest podział mecenatu według źródeł finansowania, a więc na mecenat dworski, mieszczański, państwowy, itp., ponieważ terminu tego można używać jedynie w odniesieniu do jednostki. Jeżeli funkcje opiekuńcze wobec sztuki wypełniają grupy społeczne, bądź przedstawiciele urzędów państwowych - realizują oni „politykę artystyczną", a nie uprawiają mecenatu $^{16}$.

Ta ostatnia sugestia musi zostać podjęta przez historyków książki ostrożnie. Konsekwencja przyjęcia toku rozumowania J.A. Chrościckiego dla interesującego nas obszaru publikacji byłaby konieczność wyeliminowania zbiorowego mecenatu wydawniczego, a ograniczenie się jedynie do mecenatu indywidualnego. Trzeba 
się zgodzić z autorem, kiedy protestuje on przeciwko terminowi "mecenat urzędowy" czy nadużywanemu w sposób oczywisty „mecenatowi Państwa". Państwo, rzeczywiście, realizuje z podatków swoich obywateli, poprzez finansowanie działalności kulturalnej, swoją politykę. Gdybyśmy chcieli jednak rozciagnąć to zastrzeżenie na XIX-wieczne instytucje społeczne, sprawa się komplikuje. Działalność Kasy im. Mianowskiego, przyjmując zastrzeżenia J.A. Chrościckiego, nie nosiłaby charakteru mecenatu, a byłaby jedynie fragmentem prowadzonej przez tę instytucję polityki naukowej, w której skład wchodziło subwencjonowanie wydawnictw. Bezsprzecznie, ta działalność, tak jak podobna w tym okresie działalność Akademii Umiejętności w Krakowie, były fragmentem polityki oporu wobec zaborców. Publikowane teksty historyczne budowały i umacniały świadomość historyczną Polaków, a publikacje z nauk ścisłych skłaniały młodzież do podejmowania nauki w kierunkach, w jakich zmierzała współczesna cywilizacja. Gdy jednak spojrzeć na źródła finansowania i jego motywy - perspektywa się zmienia. Stowarzyszenia te finansowały swoje akcje ze składek lub dotacji ludzi prywatnych nie oczekujących na żadne doraźne korzyści. Stanowiły więc klasyczny przykład mecenatu w formie o wiele bardziej „czystej” czy „idealnej” od indywidualnego, gdyż omalże anonimowego. Można by wprawdzie zgłosić zastrzeżenie, że działania mające charakter społeczno-polityczny, nawet te nastawione na dalszą metę, choć nie mają na względzie utylitarnie rozumianych korzyści, w odległym horyzoncie czasowym mają również na względzie korzyści członków społeczeństwa, jednakże pêrspektywa ta jest tak odległa, że nie może zachwiać przekonania o bezinteresowności motywów ludzi subwencjonujących wydawnictwa.

Między historykami książki a historykami sztuki zarysowane wyżej różnice w rozłożeniu akcentów określających konstytutywne cechy mecenatu wynikają przede wszystkim z odmiennych statusów przedmiotów będących obiektem badań. Historycy sztuki mają większy kłopot nie tylko z wyodrębnieniem zupełnie bezinteresownej działalności mecenasowskiej, ale w ogóle z taką kwalifikacja. Czy wybudowanie pałacu lub kamienicy jest po prostu inwestycją sfinansowaną dla własnej wygody, czy wspieraniem architektury danej epoki? Czy wyposażenie pałacu w dzieła sztuki jest fragmentem budowania własnego prestiżu, czy płynie z umiłowania sztuki i chęci pomocy artystom? Odpowiedzi na takie pytania są złożone, a niektórych kwestii nie wyjaśni się nigdy do końca.

Problemy bibliologa są mniej skomplikowane. Książi, niezależnie z jakich pobudek sfinansowane i wydane, „odrywają się” od swoich twórców - rozpoczynają własny, autonomiczny żywot w każdym społeczeństwie. Nie można w tym wypadku mówić o jakichkolwiek utylitarnych pobudkach towarzyszących ich wydaniu publikacja książek naukowych związana była z reguły ze stratami. Motywami takich działań były często pobudki ambicjonalne, mniej czy bardziej czytelne w programach wydawniczych poszczególnych mecenasów. Od motywów takich nie jest zresztą wolna żadna tego typu działalność. Pobudki takie osłabiają oczywiście, pewność z jaką chcielibyśmy nazwać XIX-wiecznych wydawców ksiażek krystalicznie bezinteresownymi mecenasami, nie przekreślajajednak, jak się wydaje, istoty tej kwalifikacji. Dlatego też mimo ostrzeżeń, które słusznie wnoszą historycy sztuki, na pytanie zawarte w tytule tego artykułu trzeba odpowiedzieć twierdząco. 


\section{Przypisy}

${ }^{1} \mathrm{Z}$. Gaca-Dąbrowska, Sytuacja w badaniach nad dziejami bibliotek i bibliotekarstwa XIX i XX w. „Studia o Ksiazżce" 1982, t. 12, s. 75-76.

${ }^{2}$ R. Marciniak, A. Mężyński, Polskie biblioteki wielkoziemiańskie (rodowe, ordynackie i fundacyjne) w okresie zaborów. Stan badań i postulaty badawcze. Cz. 1, „Studia o Książce” 1985, t. 15, s. 191-210; Cz, 2, tamże, 1986, t. 16, s. 235-263.

${ }^{3}$ A. Mężyński, O potrzebie i metodach badania prywatnego mecenatu wydawniczego $w$ dziedzinie publikacji naukowych $w$ XIX w. "Studia o Książce" 1982 , t. 12 , s. $47-58$.

${ }^{4}$ A. Biernacki, „W interesie Długoszowym” Aleksandra Przeździeckiego starania i zasługi, W:] Studia i Materiały z Dziejów Nauki Polskiej. Seria A. Historia nauk społecznych. Z. 16, Warszawa 1984, s. $111-124$.

${ }^{5}$ A. Mężyński, Jan Dziahyński 1829-1880, Wrocław 1977.

${ }^{6}$ J. Dybiec, Mecenat naukowy i oświatowy w Galicji 1860-1918, Wroctaw 1981.

7 Tami̇e, s. 6.

${ }^{8}$ Tamże, s. 100.

${ }^{9}$ A. Mężyński, O potrzebie..., s. 47-48.

${ }^{10}$ O wysitku wydawniczym Raczyńskiego najpetniej informuje praca A. Wojtkowskiego: Edward Raczyński i jego dzieło, Poznań 1929.

11 J. Dybiec, op.cit., s. 100-101.

${ }^{12}$ Uwagi takie poczynił J. Bialostocki: Mecenas, kolekcjoner, odbiorca [W:] Mecenas, kolekcjoner, odbiorca, Warszawa 1984, s. 12.

${ }^{13}$ Bogate materialy na ten temat zawiera zbiór studiów z dziejów kultury polskiej XVI-XVIII w. pt. „Tryumfy i porażki”, Warszawa 1989.

${ }^{14}$ Nie wydaje się jednak, żeby można bylo mówić o jakiejkolwiek formie mecenatu, gdy w grę wchodzi wyłącznie motyw zysku, np. możliwość korzystnej odsprzedaży dziela sztuki. Mecenat pozbawiony elementów bezinteresowności przestaje być mecenatem.

15 "Dyskusja ta toczy się od lat i z pewnością trwać będzie jeszcze dziesięciolecia" - stwierdza Maria Bogucka w Przemowie do "Tryumfu i porażki", s. 6.

${ }^{16}$ J.A. Chrościcki, Czy można nazwać mecenasami polskich Wazów? [W:] „Tryumfy i porażki", s. $188,191$. 